\title{
Kualitas Gender Di Desa Karang Jeruk Kecamatan Jatirejo Kabupaten Mojokerto
}

\author{
Gender Quality in Karang Jeruk Village Jatirejo Sub-District \\ Mojokerto
}

\author{
Sari Priyanti*, Agustin Dwi Syalfina*, Dian Irawati* \\ *Sekolah Tinggi Ilmu Kesehatan (STIKES) Majapahit Mojokerto \\ (Email: sari_priyanti@yahoo.co.id;agustinpipin2@gmail.com; \\ dian.irawati80@gmail.com)
}

\begin{abstract}
ABSTRAK
Gender merupakan perbedaan antara laki-laki dan perempuan tidak hanya dilihat dari jenis kelamin secara fisik tapi didasarkan peran dan tanggung jawab yang terbentuk karena adat istiadat yang berkembang di masyarakat. Kesetaraan gender penting diperhatikan dalam meningkatkan derajat kesehatan wanita terutama kesehatan reproduksi. Penelitian ini bertujuan untuk mengidentifikasi kualitas gender. Penelitian menggunakan jenis epidemiologi deskriptif berlokasi di Desa Karang Jeruk Kecamatan Jatirejo Kabupaten Mojokerto. Sampel yang diperoleh 70 ibu dengan teknik purposive sampling. Data diolah dengan teknik univariat menggunakan SPSS. Hasil penelitian diperoleh kualitas gender kuarng baik di Desa Karang Jeruk Kecamatan Jatirejo Kabupaten Mojokerto sebesar 44.3\%. hal ini disebabkan masih ditemukan responden tidak mampu memenuhi kebutuhan kesehatan dan memiliki perbedaan menu makan karena keterbatasan pendapatan keluarga, masih mempercayai mitos yang bisa mengganggu kesehatan. pernah mendapatkan tindakan kekerasan, tidak memiliki ijin dari suami untuk melakukan kegiatan diluar rumah, tidak memiliki wewenang dalam pengaturan keuangan keluarga.
\end{abstract}

\section{Kata kunci: Kualitas, Gender, Perempuan}

\begin{abstract}
Gender is the difference between men and women, not only seen physically from sex, but also based on the roles and responsibilities formed by the customs developed in the community. Gender equality is important to note in improving women's health status, especially the health of reproduction. This research aims to identify the quality of gender. The research applies a descriptive epidemiological research located in Karang Jeruk Village, Jatirejo sub-district, Mojokerto. The obtained samples are 70 mothers selected through purposive sampling technique. The data are processed through univariate techniques by using SPSS. The results obtained from the research show a poor gender quality in Karang Jeruk Village, Jatirejo Sub-district, Mojokerto, for about 44.3\%. This is due to the fact that respondents are still unable to access their health needs and have different diet menus because of a limited family income. Other factors include still believing in myths resulted in disrupted health, experiencing acts of violence, getting no permission from their husband to do activities outside the home, and owning no authority in managing the family financial.
\end{abstract}

Keywords: Quality, Gender, Woman 


\section{PENDAHULUAN}

Kesetaraan gender dan pemberdayaan perempuan merupakan tujuan ke lima (5) dari Sustainable Development Goals (SDGs) yang merupakan upaya untuk perlindungan hak perempuan dan peningkatan kualitas hidup perempuan. Target dari kesetaraan gender yang tercantum pada tujuan pembangunan berkelanjutan meliputi penghapusan diskriminasi dan segala macam bentuk kekerasan pada perempuan, menghapus praktik berbahaya seperti pernikahan usia dini, pernikahan paksa dan khitan pada perempuan, kesempatan untuk partisipasi yang sama, penuh dan efektif pada perempuan dalam kehidupan ekonomi, politik dan masyarakat, jaminan terhadap akses untuk mendapatkan pelayanan kesehatan seksual dan kesehatan reproduksi (Komnasham, 2017).

Komisi Nasional Hak Asasi Manusia (Komnasham) mengatakan bahwa kurang lebih 3000 sampai dengan 6500 kasus pertahun merupakan kasus kekerasan terhadap perempuan, dengan kekerasan fisik yang menduduki peringkat pertama dan kekerasan seksual peringkat kedua. Female genital mutilation (khitan pada anak perempuan) juga masih banyak dilakukan di seluruh penduduk Indonesia, pelayanan kesehatan perempuan masih belum fokus pada kesehatan tentang hubungan seksual, kontrasepsi dan reproduksi wanita (Komnasham, 2017).

Angka kematian ibu pencapaiannya dari tahun ke tahun yang cukup tinggi di Indonesia dikarenakan masih rendahnya upaya dalam penanganan tentang kesehatan reproduksi wanita serta kurangnya pengetahuan baik ibu, suami dan keluarga tentang kesehatan reproduksi wanita. Pengaturan jarak kehamilan yang kurang tepat (kurang dari dua tahun) merupakan salah satu penyebab kematian ibu karena kurangnya kepedulian suami dalam mengatur jarak kehamilan sehingga ibu harus hamil dalam kondisi jarak kehamilan yang terlalu dekat dengan kehamilan sebelumnya, meskipun kondisi ini sangat membahayakan bagi kesehatan produksi ibu dan kesehatan janinnya. Penyebab kedua kematian ibu adalah unsafe abortion karena kehamilan ibu tidak diinginkan sehingga harus mengakhiri kehamilan dengan cara yang tidak aman. Hal ini dilakukan karena faktor ekonomi yang tidak memungkinkan untuk menambah jumlah anak lagi, 
Sari Priyanti*, Agustin Dwi Syalfina*, Dian Irawati* : Gender Quality in Karang Jeruk Village .....

faktor usia ibu yang sudah tua dan anaknya sudah besar sehingga malu apabila harus memiliki bayi, korban perkosaan atau hamil diluar nikah (Subiyantoro, 2005).

Angka kematian ibu (AKI) di Indonesia pada tahun 2012 sebesar 359 per 100.000 kelahiran hidup. Angka tersebut meningkat cukup tajam dari capaian sebelumnya sehingga tidak memungkinkan untuk tercapainya target AKI sebesar 102 per $100.000 \mathrm{KH}$ pada tahun 2015. Hal tersebut diikuti oleh peningkatan AKI propinsi jawa timur yaitu 97,43 per $100.000 \mathrm{KH}$ tahun 2012. Capaian AKI di Kabupaten Mojokerto mengalami peningkatan yang signifikan mulai tahun 2012 sampai dengan tahun 2017 yaitu tahun 2012 sebesar 117 per $100.000 \mathrm{KH}$ sedangkan 2017 sebesar 174 per 100.000 KH. Menurut (Wibowo, 2011) bahwa wilayah dengan capaian AKI angka kematian rendah dikarenakan pertolongan persalinan yang aman untuk ibu dan bayi. Hal ini dipengaruhi oleh kesetaraan status sosial ibu dengan suami, dukungan sosial terhadap kesehatan ibu. Sedangkan daerah dengan AKI tinggi disebabkan karena perilaku pertolongan persalinan yang tidak aman dipengaruhi oleh rendahnya dukungan sosial terhadap perilaku sehat dan dukungan finansial suami (Wibowo, 2011). Berdasarkan latar belakang tersebut, Tujuan penelitian ini untuk mengetahui kualitas gender ibu di Desa Karang Jeruk Kecamatan Jatirejo Kabupaten Mojokerto Tahun 2018.

\section{METODE}

Penelitian ini menggunakan penelitian epidemiologi deskriptif dengan pendekatan kuantitatif yang dilaksanakan di Desa Karang Jeruk Kecamatan Jatirejo Kabupaten Mojokerto pada bulan Oktober sampai dengan Desember Tahun 2018 dengan populasinya adalah seluruh Wanita usia subur yang sudah menikah di Desa Karang jeruk. Sampel diperoleh dengan menggunakan teknik purposive sampling dengan kriteria inklusi meliputi wanita usia subur (15-49 tahun), status menikah, bertempat tinggal di Desa Karang jeruk, kooperatif, bisa membaca dan menulis dan terdapat 70 responden. sedangkan populasi yang tidak termasuk sampel dengan kriteria tidak bertempat tinggal di Desa Karang jeruk, Wanita yang sudah menikah usia lebih dari 49 tahun dan tidak kooperatif. Pengumpulan data dilakukan dengan teknik wawancara terstruktur dengan 
menggunakan kuesioner. Wawancara dilaksanakan dengan melakukan kunjungan rumah responden.

HASIL

Berdasarkan hasil kunjungan rumah dan wawancara berikut hasil penelitian tentang karakteristik responden dan kualitas gender di Desa Karang Jeruk Kecamatan Jatirejo Kabupaten Mojokerto.

Tabel 1 Distribusi Karakteristik Responden

\begin{tabular}{lcc}
\hline \multicolumn{1}{c}{ Karakteristik } & Frekuensi & $\%$ \\
\hline Umur & & \\
$<20$ th & 4 & 5,7 \\
$20-35$ th & 59 & 84,3 \\
$>35$ th & 7 & 10 \\
\hline Pendidikan & 55 & 78,6 \\
SD - SMP & 15 & 21,4 \\
SMA - PT & & \\
\hline Pekerjaan & 49 & 70 \\
Tidak bekerja & 21 & 30 \\
Bekerja & & \\
Paritas & 21 & 30 \\
Primipara & 49 & 70 \\
Multipara & & 15,7 \\
\hline Sumber informasi & 11 & 75,7 \\
Media cetak dan elektronik & 53 & 8,6 \\
Tenaga kesehatan Masyarakat & 6 & . \\
\end{tabular}

Berdasarkan Tabel 1 menunjukkan bahwa hampir seluruhnya responden berumur 20-35 tahun (84,3\%) dan sebagian kecil berumur $<20$ tahun $(5,7 \%)$, Distribusi Karakteristik Responden Berdasarkan Pendidikan hampir seluruh responden berpendidikan SD-SMP (78,6\%). Berdasarkan Pekerjaan responden sebagian besar merupkan tidak bekerja (70\%) hanya sebagai ibu rumah tangga dan hampir setengah responden (30\%) bekerja selain juga menjadi ibu rumah tangga. Sebagian besar responden memiliki paritas multipara (70\%) yaitu memiliki jumlah anak 1 dan hampir setengah termasuk paritas primipara (30\%) dengan jumlah anak lebih dari 1 . Informasi tentang gender perempuan yang mempengaruhi kesehatan reproduksi wanita, berdasarkan sumber informasi tersebut sebagian besar mendapatkan informasi dari tenaga kesehatan $(75,7 \%)$ dan sebagian kecil dari masyarakat (8,6\%). 
Sari Priyanti*, Agustin Dwi Syalfina*, Dian Irawati* : Gender Quality in Karang Jeruk Village .....

Tabel 2 Distribusi Kualitas Gender Responden

\begin{tabular}{|c|c|c|}
\hline Kualitas Gender & Frekuensi & $\%$ \\
\hline Kurang Baik & 31 & 44,3 \\
\hline Baik & 39 & 55,7 \\
\hline Jumlah & 70 & 100 \\
\hline
\end{tabular}

Hasil penelitian tentang kualitas gender responden menurut Tabel 2 yaitu kualitas gender dalam kategori kurang baik dan baik memiliki proporsi yang sama sebesar 44,3\% untuk kurang baik dan 55,7\% untuk yang baik.

Tabel 3 Distribusi Kuesioner Tentang Kualitas Gender Responden

\begin{tabular}{|c|c|c|}
\hline Kualitas Gender & Frekuensi & $\%$ \\
\hline \multicolumn{3}{|l|}{ Pola Makan Perhari } \\
\hline Tidak tentu & 5 & 7,1 \\
\hline 1-2x/hari & 6 & 8,6 \\
\hline 3x/hari & 59 & 84,3 \\
\hline \multicolumn{3}{|l|}{ Perbedaan Menu Makan } \\
\hline Ya & 20 & 28,6 \\
\hline Tidak & 50 & 71,4 \\
\hline \multicolumn{3}{|l|}{ Jam Istirahat } \\
\hline Kurang & 17 & 24,3 \\
\hline Cukup & 53 & 75,7 \\
\hline \multicolumn{3}{|l|}{ Penghasilan Suami/Bulan } \\
\hline$<\mathrm{UMR}$ & 45 & 64,3 \\
\hline$\geq \mathrm{UMR}$ & 25 & 35,7 \\
\hline \multicolumn{3}{|c|}{ Dana Untuk kepentingan Kesehatan } \\
\hline Tidak Ada & 50 & 71,4 \\
\hline Ada & 20 & 28,6 \\
\hline \multicolumn{3}{|c|}{ Tempat Pemeriksaan Kesehatan } \\
\hline Dukun & 0 & 0 \\
\hline Tenaga Kesehatan & 70 & 100 \\
\hline \multicolumn{3}{|c|}{ Jarak Tempat Pelayanan Kesehatan } \\
\hline$\geq 1 \mathrm{~km}$ & 43 & 61,4 \\
\hline$<1 \mathrm{~km}$ & 26 & 38,2 \\
\hline \multicolumn{3}{|l|}{ Kebebasan BerKB } \\
\hline Tidak & 0 & 0 \\
\hline Ya & 70 & 100 \\
\hline \multicolumn{3}{|c|}{ Kebebasan Menentukan Kehamilan } \\
\hline Tidak & 0 & 0 \\
\hline Ya & 70 & 100 \\
\hline \multicolumn{3}{|c|}{ Kepercayaan Tentang Mitos Pada Kehamilan } \\
\hline Ya & 48 & 68,6 \\
\hline Tidak & 22 & 31,4 \\
\hline \multicolumn{3}{|c|}{ Pernah Mendapatkan Tindakan Kekerasan } \\
\hline Ya & 2 & 2,9 \\
\hline Tidak & 68 & 97,1 \\
\hline \multicolumn{3}{|c|}{ Keterlibatan Dalam Pengambilan Keputusan Dalam Keluarga } \\
\hline Tidak & 0 & 0 \\
\hline Ya & 70 & 100 \\
\hline
\end{tabular}




\begin{tabular}{lcc}
\hline Kualitas Gender & Frekuensi & $\%$ \\
\hline Kesempatan Mengikuti Kegiatan Diluar Rumah & & \\
$\quad$ Tidak & 1 & 1,4 \\
$\quad$ Ya & 69 & 98,6 \\
$\begin{array}{l}\text { Memegang Kuasa Dalam Pengaturan Keuangan Keluarga } \\
\text { Tidak }\end{array}$ & 21 & 30 \\
Ya & 49 & 70 \\
\hline \multicolumn{1}{c}{ Jumlah } & 70 & 100
\end{tabular}

Tabel 3 hampir seluruh responden (84,3\%) untuk pola makan dalam sehari sebanyak 3 kali dan sebagian besar $(71,4 \%)$ tidak ada perbedaan menu makan dengan anggota keluarga yang lain namun sebagian kecil (28,6\%) menu makan ibu ada perbedaan dengan anggota keluarga lain. Jam istirahat untuk responden sebagian besar (75,7\%) dalam kategori cukup dan dengan jumlah penghasilan suami perbulan kurang dari UMR (64,3\%). Apabila responden dan keluarga ada keluhan dengan kesehatan, pemeriksaan kehamilan seluruhnya (100\%) melakukan pemeriksaan pada tenaga kesehatan karena jarak ke tempat pelayanan kesehatan sebagian besar $(61,4 \%)$ kategori dekat $(<1 \mathrm{~km})$ akan tetapi sebagian besar responden $(71,4 \%)$ memiliki hambatan terhadap biaya kesehatan karena tidak ada anggaran dari penghasilan keluarga untuk kesehatan dan hanya cukup untuk memenuhi kebutuhan pokok keluarga.

Seluruh responden memiliki kebebasan dalam menentukan kehamilan dan memilih kontrasepsi yang digunakan untuk mengatur jarak kehamilan, akan tetapi sebagian besar responden (68,6\%) masih percaya terhadap mitos tentang kehamilan. Hampir seluruh responden $(97,1 \%)$ tidak pernah mengalami tindakan kekerasan dalam rumah tangga baik fisik, psikis dan sosial akan tetapi ada sebagian kecil responden (2,9\%) yang mendapatkan bentuk kekerasan rumah tangga. 98,6\% responden diberi kesempatan sama suami untuk bisa mengikuti aktifitas lain di luar rumah seperti PKK, arisan RT, pengajian, dan sebagainya dan 1,4\% tidak diberi ijin oleh suami untuk mengikuti kegiatan selain menjadi ibu rumah tangga. Responden sebagian besar (70\%) memiliki wewenang dalam mengatur keuangan rumah tangga dan hampir setengah responden (30\%) tidak berwenang tentang pengaturan keuangan rumah tangga. 
Sari Priyanti*, Agustin Dwi Syalfina*, Dian Irawati* : Gender Quality in Karang Jeruk Village .....

\section{PEMBAHASAN}

Berdasarkan hasil penelitian menunjukkan bahwa hampir seluruh respoden berumur 20-35 tahun, berpendidikan SD-SMP, memiliki peran sebagai ibu rumah tangga, anaknya lebih dari dua dan mendapatkan segala informasi tentang kesehatan dari tenaga kesehatan. Pendidikan dan keterampilan yang rendah pada perempuan dengan kondisi sosial ekonomi keluarga memaksa perempuan menjalankan peran transisi sebagai pekerja dengan upah rendah tetapi jam kerja tidak menentu dan panjang (Wibowo, 2011). Adat istiadat yang berkembang di masyarakat membelenggu perkembangan derajat perempuan dimana perempuan harus tinggal di rumah, pendidikan tidak harus tinggi, pekerjaan rumah tangga merupakan tugas wanita. Hal ini sejalan dengan penelitian ini responden perempuan hampir seluruhnya berpendidikan dasar dan hanya bisa bekerja sebagai buruh dengan gaji dibawah UMR karena latar belakang pendidikan dan keterampilan sangat rendah (Wibowo, 2011). Di Indonesia laki-laki dan perempuan diberikan peluang yang sama dalam hal pendidikan namun persepsi masyarakat tetap bahwa wanita bertugas sebagai istri yang mendampingi suami, mendidik anak, disamping menjalankan aktifitas diluar rumah baik bekerja dan keikutsertaan dalam organisasi. Peran laki-laki tidak pernah didefinisikan secara tegas pada kalangan masyarakat (Nauly, 2002).

Kualitas gender kurang baik dan baik berproporsi sama di Desa Karang Jeruk Kecamatan Jatirejo Kabupaten Mojokerto Tahun 2018 karena masih ada ibu yang hak sebagai perempuan dan aspek yang menunjang kesehatan reproduksi belum terpenuhi misalnya ada perbedaan menu makan ibu, kurangnya jam istirahat, tidak ada biaya dalam pemenuhan kesehatan diri dan keluarganya, kepercayaan pada mitos yang merugikan kesehatan, kekerasan dalam rumah tangga, tidak adanya kesempatan dalam mengikuti kegiatan diluar rumah serta dalam pengaturan keuangan keluarga. Hasil penelitian ini sejalan dengan penelitian yang dilakukan oleh (Susanti, 2014) yaitu berperspektif positif dan negatif tentang gender tidak jauh beda sebesar 53\% dan $47 \%$ karena sebagian besar pernyataan positif tentang pemimpin keluarga, pencari nafkah, pengambil keputusan adalah suami, suami tidak boleh melakukan pekerjaan rumah tangga, 
serta istri harus selalu menyiapkan kebutuhan suami dan mencari nafkah tambahan untuk keluarga.

Aspek jenis kelamin laki-laki dan perempuan memang memiliki perbedaan dalam tampilan fisik akan tetapi perbedaan ini tidak bisa menjadi alasan terhadap terjadinya ketidakadilan pada perempuan karena laki-laki adalah pihak yang kuat, berkuasa dan derajat yang tinggi, oleh karena itu penting ada keseteraan antara laki-laki dan perempuan yang kita sebut kesetaraan gender (Hermawati, 2007). Gender mengandung arti jenis kelamin. Gender disini bukan membedakan jenis kelamin antara laki-laki dan perempuan berdasarkan biologis dan hormonal tetapi melihat hak, peran, tanggung jawab antara laki-laki dan perempuan yang terbentuk oleh budaya dan lingkungan dimana mereka dibesarkan (Subiyantoro, 2005).

Berdasarkan norma sosial kedudukan wanita dan pria memiliki peran, kedudukan, hak dan kewajiban yang sama akan tetapi wanita jauh tertinggal di segala aspek akibat adat istiadat yang berkembang di masyarakat Indonesia. Hal ini sering memberikan dampak negatif kepada kesehatan reproduksi perempuan misalnya peran domestik perempuan sebagai ibu rumah tangga disertai peran untuk mencari nafkah membantu ekonomi keluarga yang menyebabkan kelelahan baik secara fisik maupun emosional sehingga kualitas hidup wanita rendah (Sudarta, 2007). Pada penelitian ini ada beberapa ibu dengan waktu istirahat yang kurang dan pendapatan keluarga kurang dari UMR.

Tingkat sosial ekonomi keluarga yang rendah merupakan penyebab tidak langsung tingginya capaian maternal mortality. Kondisi sosial ekonomi berdampak pada kualitas pemenuhan kebutuhan gizi dan jangkauan terhadap pelayanan kesehatan. Sosial ekonomi rendah disertai keterbatasan untuk asupan gizi sehingga menyebabkan ibu hamil dengan kondisi kekurangan gizi yang merupakan faktor risiko perdarahan pada persalinan dan salah satu penyebab kematian (Rajab, 2009).

Penelitian ini menunjukkan masih ada responden berbeda menu makan dengan anggota lain, jumlah makan perharinya tidak bisa ditentukan karena faktor ekonomi serta masih percaya pada mitos yang menyebabkan gangguan pada 
Sari Priyanti*, Agustin Dwi Syalfina*, Dian Irawati* : Gender Quality in Karang Jeruk Village .....

kesehatan reproduksi. Menurut (Hartiningtiyaswati, 2010), ibu yang pantang makan pada masa nifas penyembuhan luka perineum lebih lama dibandingkan yang tidak pantang makan. Menurut penelitian (Syalfina, 2016). Pola makan ibu nifas merupakan faktor risiko terhadap penyembuhan luka perineum. Wanita menikah dan hamil harus tinggal mengikuti suami dan seatap dengan mertua menyebabkan kebebasan dalam pemenuhan kebutuhan dirinya sendiri terbatas baik dari segi pemeriksaan kesehatan dan menu makan karena mitos yang masih dipercaya oleh mertua dan keluarga.

\section{SIMPULAN}

Penelitian ini menunjukkan 44,3\% responden dengan kualitas gender kurang baik dan 55,7\% kategori baik dengan berumur 84,3\% berusia 20-35 tahun, 78,6\% pendidikan terakhir SD-SMP, 70\% tidak bekerja, 70\% multipara dan 75,7\% sumber informasi tentang kesehatan dari tenaga kesehatan. Diharapkan tenaga kesehatan mensosialisasikan kepada masyarakat, suami, keluarga tentang pentingnya keseteraan gender terhadap kesehatan reproduksi wanita dan bagi peneliti selanjutnya karena keterbatasan peneliti diharapkan melakukan analasis pengaruh kualitas gender terhadap kejadian mortalitas atau morbiditas ibu.

\section{UCAPAN TERIMA KASIH}

Terima kasih kami haturkan pada Sekolah Tinggi Ilmu Kesehatan Majapahit Mojokerto atas dukungan dana dan ijin terhadap penelitian kami, kepala Desa Karangjeruk Kecamatan Jatirejo Kabupaten Mojokerto atas pemberian ijin penelitian serta rekan sejawat dan tim peneliti yang telah membantu terselesaikannya penelitian kualitas gender.

\section{DAFTAR PUSTAKA}

Hartiningtiyaswati, S. (2010) Hubungan Perilaku Pantang Makanan Dengan Lama Penyembuhan Luka Perineum Pada Ibu Nifas Di Kecamatan Srengat Kabupaten Blitar. Surakarta. Available at: dari https://eprints.uns.ac.id/6259/.

Hermawati, T. (2007) 'Budaya Jawa dan Kesetaraan Gender', Jurnal Komunikasi Massa, 1(1), pp. 18-24.

Komnasham (2017) Kerangka Analisis Untuk Mengintegrasikan Tujuan Pembangunan Berkelanjutan (Sdgs) Dengan Kewajiban Pemenuhan Hak-

Hak Asasi Manusia Untuk Di Indonesia. Available at:


https://sdg.komnasham.go.id/sdg-content/uploads/2017/04/Tujuan-5.pdf (Accessed: 3 March 2019).

Nauly, M. (2002) Konflik Peran Gender pada Pria: Teori dan Pendekatan Empirik. Available at: http://repository.usu.ac.id/handle/123456789/3502.

Rajab, U. B. (2009) 'Kematian Ibu: Suatu Tinjauan Sosial-Budaya', Jurnal Masyarakat \& Budaya, 11(2), pp. 237-254.

Subiyantoro, E. B. (2005) Sensitivitas Gender Kebijakan Pemerintahan Sby. Available at: https:/www.theindonesianinstitute.com/wpcontent/uploads/2014/02/11-Policy-Assessment-Sensitivas-Gender-olehEko-Bambang-Subiyantoro-Juni-2005.pdf.

Sudarta, W. (2007) 'Peranan Wanita Dalam Pembangunan Berwawasan Gender', Jurnal Studi Jender SRIKANDI, 3(1), pp. 1-12. Available at: https://ojs.unud.ac.id/index.php/srikandi/article/view/2758.

Susanti, S. (2014) 'Perspektif Gender Pada Masyarakat Sundadi Desa Cikunir Kecamatan Singaparna Kabupaten Tasikmalaya Tahun 2013', Jurnal Bidkesmas, 2, pp. 20-29.

Syalfina, A. (2016) 'Faktor Yang Berpengaruh Terhadap Penyembuhan Luka Perineum Pada Ibu Nifas', in Membumikan UU No.18 Tahun 2014 Tentang UU kesehatan Jiwa Masyarakat. IAKMI Jabar Dan Pasca Sarjana IKM UNPAD. http://ejurnalp2m.stikesmajapahitmojokerto.ac.id/index.php/publikasi_stikes _majapahit/issue/view/16/showToc.

Wibowo, D. E. (2011) 'Peran Ganda Perempuan Dan Kesetaraan Gender', Jurnal Muwazah, 3(1), pp. 356-364. Available at: diakses dari http://ejournal.iainpekalongan.ac.id/index.php/Muwazah/article/view/6. 